\title{
Halal Food as Gastronomy Tourism Strategy: Opportunities and Challenges for Indonesian Economy
}

\author{
Aula Nurul Ma'rifah ${ }^{1}$, Estelee Elora Akbar ${ }^{2}$, Umi Rohmah ${ }^{3}$, Sela Nur Fitria ${ }^{4}$, Nurul \\ Hidayati $^{5}$ \\ \{aulanurul15@gmail.com ${ }^{1}$, esteleeeloraakbar@gmail.com² ${ }^{2}$, selanurfitria1@gmail.com ${ }^{4}$, \\ ululhidayati93@gmail.com ${ }^{5}$ ?
}

1,2,3,4,5 State Islamic University Graduate Program of RadenIntan Lampung, Indonesia

\begin{abstract}
The purpose of this study is to identify opportunities and challenges of the Indonesian economy with halal food as a gastronomy Tourism strategy. This study is a qualitative study using secondary data. The study found thatthe majority of Muslim population in Indonesia is considered as the opportunities for increasing the Indonesian economy through halal food as gastronomy tourism strategy.Moreover, non-Muslims who consumed halal food are indicated by the content of halal food that are healthy, clean and completed with quality. Global market competitions are challenges to be faced by Indonesia in improving the country's economy, not only local food to be considered as halal food in Indonesia, however, a variety of foods from other countries that have been certified as halal also found in Indonesia.
\end{abstract}

Keywords: Halal Food, Gastronomy Tourism Strategy, Indonesia Economy

\section{Introduction}

Homelandof Indonesia has become a magnet of other countries to explore Indonesia because the Indonesian archipelago had assets of its abundant natural resources and not shared by other countries, especially Europe. Spices owned by Indonesia is not present in the land of Europe, with owned spices are making Indonesia as a contention country by other countries. This caused Indonesia was colonized by Netherlands in the past. Not only the past, in this present era, Indonesia is still regarded as a fertile country in natural resources. Therefore, complex developments that occurred in the current era of civilization require renewal that occurred in Indonesia in order to compete andmaintain the immunity, especially in the field of economy. One of ways that can be conducted by Indonesia is by implementing the gastronomy tourism strategy.

Gastronomy tourism is a form of culinary tourism to strengthen the country's economy with a form of public diplomacy to attract tourists in the international arena[1]. Nikos, et.al stated that gastronomy has offered benefits in the social and economic fields for the Greek state in a sustained period[2].Other findings found that the Thailand state through Gastronomy can introduce the identity of themselves to the world with culinary tied to the culture[3]. Gastronomy strategies are not necessarily able to do so alone, international standardization that has elements of lifestyle must be met such as the element of historical, cultural elements, local products, food that can be told and nutrients that are met andthe culinary that reflects the identity[4].Gastronomy developed into a tourism product that is gastronomy tourism.

Gastronomy tourism is a form of strategy to export culture more broadly, especially in the field of cuisine[5].Gastronomy tourism has the potential to increase the rate of the 
country's economy. The imbalance of information flow and communication between countries affect to the ignorance of matters related to developing countries. For developing countries,gastronomytourism is helpful in shaping national branding and known to the international community. One of gastronomy tourism strategy that can be done by Indonesia in improving the country's economy is halal food.

Nationalism and food have been a connection in international relations[6]. The food not only as a tourism product which will affect the economy of a country, but also as an image of the nation[7]. Halal food has stolen the attention of foreign countries. Halal food is a place to unite one individual and others individuals, or a group and others groups even to unite the international public regardless of religion, ethnic, culture and other differences[8]. As a country with majority of Muslim, Indonesia requires the credibility on halal food spread in Indonesia. Consuming halal food is the duty of Muslims either the foodprocessed bythem or the food in the form of packaging and food available at the restaurant. Here is a list of countries that have a Muslim majority population:

Indonesia is the country with the highest Muslim population in the world with a total of 204.847.000 inhabitants, followed by Pakistan amounted to 178.097.000, India amounted to 177.286.000, Bangladeshamounted to148.607.000, Egypt amounted to 80.024.000, Nigeria amounted to 75.728.000, Iran amounted to 74.819.000, Turkey amounted to 74.660.000, Algeria amounted to 34.780.000, and Morocco amounted to 32.381.000 (Forum on Religion \& Public Life, 2019). While for the other countries have Muslim population with a low number even included the minority. Indonesia, which has a Muslim majority population can make gastronomy tourism as a strategy to campaign for halal food to attract the attention of tourists, both domestic and foreign, and then will have implications for the economy of Indonesia.

\section{Method}

This study is a qualitative study using secondary data obtained from the supported study of literature and documentation in this study, by implementing a qualitative descriptive analysis method.

\section{Results and Discussion}

\subsection{Opportunities and Challenges ForIndonesian Halal Food as Gastronomy Tourism Strategy}

Islam is a religion that formed the behavior of people, culture and customs. The concept of Sharia has become a trend in the overall economic progress [9]. The increasing population of Muslims in the world cause Islam ranks second order as belief embraced by humans in various parts of the world. Muslim population in the world has recorded significant growth from year to year. 


\section{Diagram 1 \\ Muslim Growth Projections in 2015-2060}

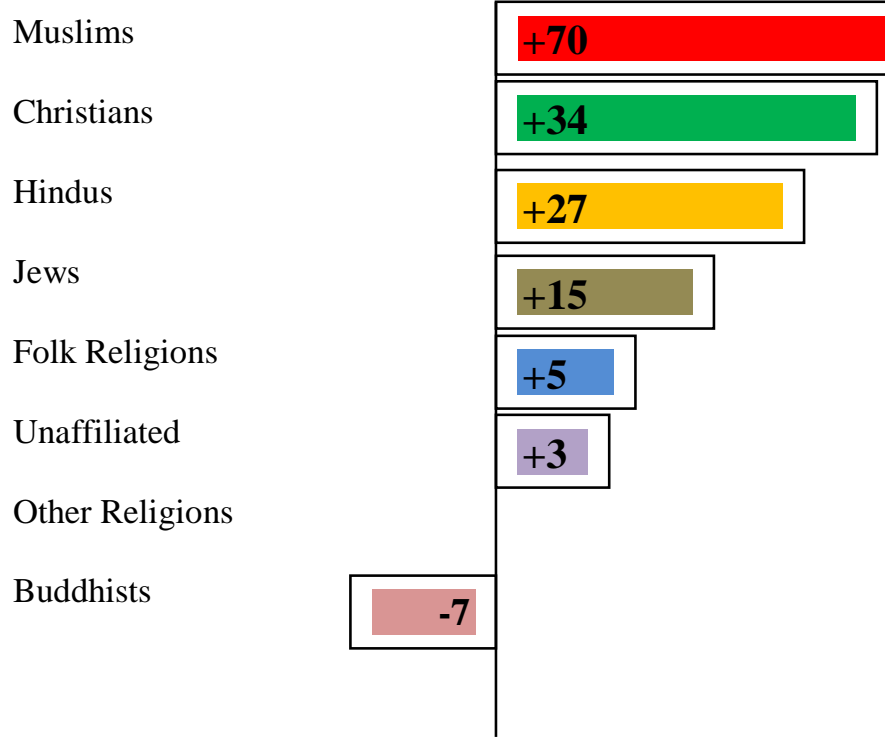

Based on the above diagram, it informsthat all religions will experience a fluctuating movement of population number for people who embraces the belief in the world. Muslim regarded as the population that will grow more rapidly in the world during 2015-2060[10]. It is an opportunity for Indonesia as a country with a Muslim majority.

Indonesia is a country with diverse ethnicities and cultures. As a developing country, Indonesia needs substantial economic development that will encourage the management of natural resources and promote economic growth globally. As a country of Muslim majority, halal food business can be used as gastronomy tourism strategy to attract the tourists to visit Indonesia.

Indonesia won three awards at the World Halal Travel Award 2015, thatare the world's best awards halal tourism destination, world best halal honeymoon destination, and the world's best family hotel. Moreover, in the next year Indonesiagot 12 awards at the World Halal tourism in 2016. It shows how Indonesia halal tourism has been recognized by the International public. Regarding to that, it can be estimated that tourism can develop broader by developing food tourism.

The development of food tourism was done by Indonesian through gastronomy tourism to promote the culinary held on the event of 5th United Nation World Tourism Organization (UNWTO) World Forum on Gastronomy Tourism in the past May 2019 which took place in the city of San Sebastian, Spain. In that event, the ministry of Indonesia introduce a unique culinary of Indonesian archipelago and promote Indonesia globally to 157 countries[11]. Indonesia settled Ubud as gastronomy, which has the standards of UNWTO that aims to help Indonesiapositions the owned tourism in the world map (Zthe Miniatry of Tourism, Republic of Indonesia).Indonesia will perform as part of international tourism byowned culinary power includes halalculinary. Until now the number of halal products in Indonesia as many as 688.615 products with a number of companies certified as halal as many as 55.626 companies and halal certificate holders as much as 65.116 pieces. 
Food is a society permanent dialectic[12]. Eating is a human need, but the food could be a tourist attraction and the reason for one's journey[13]. One effective way in business competition is with halal food[14]. Develop halal products provide a competitive advantage[15]. Nik, et. al stated Malaysians using halal labeling in achieving the goal of marketing products and build global relationships with other countries[15].

Haque, et.al described non-Muslim communities who are in Malaysia give a positive response to halal food [16]. Acceptance of halal food that is done by non-Muslims is indicated by food safety, hygiene and quality of food[16]. Such conditions also occurred in Indonesia, namely the halal certified products must go through laboratory tests by MUI that qualified food safety, food quality, hygiene, and health so that halal food in gastronomy tourism could attract Muslims and non-Muslims tourists globally.

However, Indonesia as an open country must face the global competition with food products of other countries that have been certified halal. So far there are 451 foreign franchises were in Indonesia does not include non-franchiserestaurants[17]. This is a challenge for Indonesia culinary to face the competition from other country's culinary diversity, so that Indonesia needs to strengthen the image of the Indonesian archipelago culinary with the brand image of culinary that does not ignore the Islamic law.

\section{Conclusions}

The rapid growth of the world Muslim is an opportunity for Indonesia who also has a Muslim majority population as well as the halal certification board that have been recognized internationally and supported bywealth of culinary to develop halal food as gastronomy tourism strategy. However, Indonesia also has the challenge of competition with many products from other countries that also have been certified halal. To face the competition of products, Indonesia needs to strengthen the image of the Indonesian archipelago culinary with the brand image of culinary that does not ignore the Islamic law.

\section{References}

[1] J. Zhang, "The Foods of the Worlds: Mapping and Comparing Contemporary Gastrodiplomacy Campaigns,” vol. 9, pp. 568-591, 2015.

[2] N. Krigas, D. Lazari, E. Maloupa, and M. Stikoudi, "Introducing Dittany of Crete ( Origanum dictamnus L .) to gastronomy: A new culinary concept for a traditionally used medicinal plant," Int. J. Gastron. Food Sci., pp. 1-7, 2015.

[3] Y. Fartiannur, "KEPENTINGAN THAILAND DALAM MELAKUKAN," vol. 6, no. 4, pp. 1565-1582, 2018.

[4] R. P. F. Guiné, A. Dias, A. Peixoto, M. Matos, M. Gonzaga, and M. Silva, "Application of molecular gastronomy principles to the development of a powdered olive oil and market study aiming at its commercialization," Int. J. Gastron. Food Sci., vol. 1, no. 2, pp. 101-106, 2013.

[5] N. Nirwandy and A. A. Awang, "Conceptualizing Public Diplomacy Social Convention Culinary: Engaging Gastro Diplomacy Warfare for Economic Branding," Procedia - Soc. Behav. Sci., vol. 130, pp. 325-332, 2014.

[6] S. Chapple-sokol, "Culinary Diplomacy : Breaking Bread to Win Hearts and Minds," vol. 8, pp. 161-183, 2013.

[7] D. Syarifuddin, C. M. Noor, and A. Rohendi, "Memaknai Kuliner Lokal Sebagai Daya 
Tarik Wisata Kota Bandung,” vol. 1, no. 1, pp. 55-64, 2018.

[8] F. Othman and G. Sangaran, "Introduction to Halal Gastronomy: An Empirical Study of Halal Certiication in Kuala Lumpur's Five-Star Hotel Establishments Introduction to Halal Gastronomy: An Empirical Study of Halal Certiication in Kuala Lumpur ' $\mathrm{s}$ Five-Star Hotel Establishments," no. April 2016, 2017.

[9] W. I. Fauzi, "Islamic Tourism : A Form of Harmonization of Religion, Politics, Social , Culture and Economy," vol. 259, no. Isot 2018, pp. 355-359, 2019.

[10] Federal Department of Foreign Affairs General Secretariat Presence Switzerland, "Religious landscape," Fed. Dep. Foreign Aff. Gen. Secr. Presence Switz., 2015.

[11] Kementerian Pariwisata RI, "No Title," http://www.kemenpar.go.id/, 2019.

[12] J. Boutaud, A. Becuţ, and A. Marinescu, "Food and culture . Cultural patterns and practices related to food in everyday life . Introduction," vol. 6, no. 1, pp. 1-3, 2016.

[13] J. C. Henderson, "Halal food, certi fi cation and halal tourism : Insights from Malaysia and Singapore," TMP, 2015.

[14] M. Battour and M. N. Ismail, "Halal tourism : Concepts , practises , challenges and future," TMP, vol. 19, pp. 150-154, 2016.

[15] N. Maheran and N. Muhammad, "Positioning Malaysia as Halal-Hub : Integration Role of Supply Chain Strategy and Halal Assurance System," vol. 5, no. 7, pp. 44-52.

[16] F. Authors, "Article information :," 2015.

[17] Asosiasi Franchise Indonesia, "No Title," http://www.franchiseindonesia.or.id/, 2019. 